\title{
Fama, Notoriety, and the Due Process of Law
}

The adoption of inquisitorial procedure in secular criminal courts created a more powerful and theoretically impersonal justice system. ${ }^{1}$ But medieval 'public justice' was never really impersonal justice, in the sense of a blind Iustitia that treats every defendant and every victim the same. That modern idea would make little sense in a world where vendetta and self-help fundamentally structured community relationships, and where reputation and honor held the weight of a legal status. ${ }^{2}$ Class, wealth, gender, lineage-all these could and did affect a person's standing before the court, underscoring a particularly medieval view: if justice means giving each person his or her due, as Justinian's Code famously declares, then the nature of the person must be considered.

In medieval law, this consideration had a very specific vehicle. Fama, or public knowledge, of both persons and deeds was central to the concept of inquisition. Fama initiated trials, identified defendants, defamed witnesses, and reframed victims' narratives. It opened or closed the doors of the torture chamber, validated or invalidated testimony, and constituted the difference between rape and sex. Fama and its stronger manifestation, notorium, determined whether a defendant would be accorded a trial at all or whether the court would proceed to summary punishment. Fama was the foundation of medieval understandings of proof. Vallerani called it "the true keystone of the probatory system." ${ }^{3}$ Considering the role of fama in initiations and in framing punishments, we might go even further, and say that fama was the sine qua non of the inquisition process.

Yet as centrally important as fama was, the concept eluded concrete definitions and even probatory rules. Jurists disagreed on the number of witnesses required to prove it, and the witnesses themselves struggled to define it. Fama was real, and it existed in the community consciousness, so therefore testimony

1 Kelly, "Inquisitorial Due Process and the Status of Secret Crimes," 409.

2 See Thomas Kuehn, "Fama as a Legal Status in Renaissance Florence," in Fama: The Politics of Talk and Reputation in Medieval Europe, eds. Thelma Fenster and Daniel Lord Smail (Ithaca:

Cornell University Press, 2003), 27-46.

3 Vallerani, "How Procedures Think," 108.

(C) Joanna Carraway Vitiello, 2016 | DOI 10.1163/9789004311350_005

This is an open access title distributed under the terms of the Creative Commons AttributionNoncommercial-NonDerivative 3.0 Unported (CC-BY-NC-ND 3.0) License, which permits any noncommercial use, and distribution, provided no alterations are made and the original author(s) and source are credited. 
to it followed the same rules as testimony to other kinds of evidence. And it is important to note that the medieval emphasis on fama was not incompatible with the distrust of hearsay found in Roman law: at least formally, these were very distinct.

\section{Fama, Public Knowledge, and Proof}

The idea of fama was quite literally an idea of 'common sense' or 'common perception.' Fama itself was not a medieval invention, ${ }^{4}$ but difficult questions arose when this elusive idea was translated into a complex scholastic legal process. Inside the framework of an Aristotelian view that houses knowledge in sense perception, how does a person know and prove fama?

Jurists' definitions of fama acknowledged two primary types: fama of facts and fama of persons. Fama of facts stood as the basis of all trial initiations in the criminal court. No matter what other initiations were used-official denunciations or private querele - all inquisitions also name publica fama as an initiator, referring to the fama or public knowledge that the crime was committed and that the named defendant was known to have committed it. Personal fama became a legal status - bona fama or mala fama - and this status could confer or remove privileges in the same way that emancipation or even legitimacy could. ${ }^{5}$ It reflected public knowledge of an individual's customs and public dignity. Durantis echoes the Digest in his definition: "A status of uninjured dignity, proven by life and customs." ${ }^{\prime}$ The thirteenth-century Hostiensis wrote that fama is "public or famous insinuation or proclamation of a community, coming only from suspicion and uncertain origin." ${ }^{7}$ Fourteenth-century canonist Johannes Andreae, in his commentary on Durantis's definition, distinguished between communis fama and communis opinio, emphasizing that fama only

4 On the development of ideas and legal categories of infamy, see Peters, "Wounded names."

5 Kuehn, "Fama as a Legal Status", 31.

6 Durantis, Speculum iuris, Book III, part. I, p. 45: "Fama est illaese dignitatis status vita ac moribus comprobatus..."

7 Fama is "publica seu famosa insinuation vel proclamation communis, ex sola suspicione et incerto authore provinens..." Quoted in Jean-Philippe Lévy, La hiérarchie des preuves dans le droit savant du moyen-âge depuis la renaissance du droit romain jusqu'à la fin du XIV siècle (Paris: Librairie du Recueil Sirey, 1939), 113. 
exists as a public matter, something that is thought by the majority, while an opinion can be held by the minority. 8

Personal fama was evidenced in a pattern of behavior over time. This meant evidence of a sin or crime is not evidence of bad fama, because good people sin and sometimes commit bad acts. One of the chief characteristics of fama is that it builds over time, in the longue durée. How long? For Bartolus, personal fama or habitus "is proven from customs of three years: for from this, virtue can be determined." 9 The fundamental characteristic of fama, both of deeds and of persons, was that it existed in the public consciousness. Proving the existence of both kinds of fama therefore meant proving the existence of common knowledge. All proof in the medieval inquisitorial system rested on knowledge gained through sense perception, and the complexities begin in earnest when this amorphic concept had to be translated into a probatory system. First, how much weight should it carry, and second, how could it be proven?

Jurists struggled with the probabory value of fama. Baldus called it "probatio multum fallax et facilis," and together with Bartolus, considered it the "vana vox populi." Pierre Jacovi d'Aurillae wrote that fama is very dangerous, and often false, because it can arise from ill-intentioned people, or enemies of the accused..$^{10}$ And yet, while some jurists viewed with great suspicion the probabory value of fama, it not only continued to be used, but even became the engine of the inquisitorial process. As proof, fama of person and fama of fact were not of equal weight. Fama of fact could act as a partial proof if it were testified to by at least two witnesses. Johannes Andreae confirmed in his gloss to Durantis's Speculum iuris that fama along with one suitable witness constitutes full proof." Bartolus de Saxoferrato noted that "fama is not proof by itself, but it assists proof." ${ }^{\prime 2}$ Only a half-proof was required for a defendant to be put to torture, and significant fama could play that role. But fama of fact and fama

Johannes Andreae, addition after gloss on "Sicut," Speculum iuris, Book III, Part I. Gl. "Sicut," p. 46. “... in aliquo differunt simpliciter sumpta fama et opinio: quia fama non potest esse, nisi publica: quia est de eo, quod ab omnibus, vel maiori parte sentitur: opinio potest etiam esse talis, sed potest etiam esse paucorum, et non publica..." Bartolus, Tractatus testimoniorum, 289. "Apparet ergo, quod ex moribus trium annorum probatur habitus: ex hoc enim inducitur virtus."

10 Lévy, La hiérarchie des preuves, 114; in general see his discussion on the probatory value of fama to the jurists, $113-117$.

11 Johannes Andreae, addition after gloss on "Sicut" Speculum iuris, Book III, Part I. Gl. "Sicut," p. 46.

12 Bartolus da Saxoferrato, Commentaria in secundam Digesti veteris Partem, Venice 1570, fol. 155v. Commentary on Dig. 23.3.1: “... fama per se non probat, sed probationem coadiuuat." 
of person had a complex relationship, as Massimo Vallerani has demonstrated in his discussion of Gandinus's Tractatus, with personal fama holding stronger probative value than fama of fact. The "... fact (or the crime) is lost in favor of the fama of the person: it is engulfed in its natural habitus and becomes a secondary variable of fama."13 In other words, people were somewhat protected by their good personal fama even if fama of fact existed against them. If a person of good fama were named as a culprit by several witnesses, this alone was not enough to justify a conviction or an interrogation under torture unless other adminicula, or supporting evidence, existed. ${ }^{14}$ And for Gandinus, the opposite was also true-a person of mala fama arrested as a suspect in a crime could be put to torture more easily than a person of bona fama. A defendant of mala fama could be tortured based only on a rumor, or clamor.

How could fama be proven? Modern scholars sometimes liken fama to hearsay. ${ }^{15}$ Yet this parallel between hearsay and fama, natural as it seems, did not stand in medieval law, and when we try to understand the probatory value of fama, it is misleading. Roman law and its medieval commentators forbade testimony based on hearsay, and witnesses could testify only to what they perceived with their senses. Thomas de Piperata, whose discussion of fama was used in the fourteenth century by Bartolus, wrote that if a witness only knew about a person's fama because he had heard it discussed by other people, he could not testify to that fama. ${ }^{16} \mathrm{His}$ tract was not well-known in the fourteenth century, but his opinions are echoed by Bartolus in his Tractatus de testibus. Bartolus declared that if a witness said that something was true because he had heard it said—audivit dici- this was not probative, even if the witness claimed to have heard it from people who had themselves been eyewitnesses. ${ }^{17}$ Rather, in Bartolus's view, a witness must testify to the things he learns from his senses. This reflects the larger, fundamentally scholastic medieval view of

\footnotetext{
13 Vallerani, "How Procedures Think," 108-109.

14 Vallerani, "How Procedures Think," 110.

15 The introduction to a recent collection of essays on fama comments that "Modern legal systems rigorously try to exclude hearsay evidence... It is startling for the non-specialist, therefore, to realize that medieval legal systems readily acknowledged the force of common opinion and even devised ground rules for its use." Fama: The Politics of Talk, eds. Smail and Fenster, 3 .

16 Fraher, "Conviction According to Conscience," 34.

17 Bartolus, Tractatus testimoniorum, 240: "Testis dixit aliqua vera esse quia audivit dici. Receptum est testimonium de auditu alieno regulariter non valere... Non enim testi creditur, nisi in iudicio per iudicem iuramento prestito parte presente vel contumace solemniter examinetur, sed cum testis audivit alium se audivisse dicentem, ista solemnitas defuit: igitur insufficiens causa est."
} 
proof, which rested on an Aristotelian concept of knowledge derived from the senses. It is this idea, that witnesses must demonstrate the legitimacy of their knowledge, the iusta causa et legitima scientia, that separated testimony on fama from hearsay.

This sentiment was echoed by other jurists in their discussions of the evaluation of witness testimony. Nellus da San Gimignano followed Bartolus when he wrote that "Credence should not be placed in a witness concerning the infamy of anyone, unless he shows just cause and legitimacy of knowledge."18 In this view, Vallerani's observation that the fama of the person was "able to overthrow the scale of criteria of veracity imposed on the sensory perception of the facts" may need to be somewhat moderated. ${ }^{19}$ Personal fama was still a fact, if not a deed, and it was subject to sensory proof. Indeed, to Bartolus, all fama derived from sensory knowledge. How can a witness have sensory knowledge of "common knowledge"? Bartolus considered testimony to a person's life and customs to be probatory based on the witnesses' relationship to the accused, perhaps as a close relative or neighbor. ${ }^{20}$ Trial records reveal that witnesses who were not neighbors or relatives proved a person's fama by describing a person's behaviors, and by describing their own interactions with the person.

On October 19, 1386, Guadagninus de Placena accused a certain Meninus of committing adultery with his wife Dominica. Guadagninus made it clear in his accusation that his wife lived with him honestly, honestate viventem cum dicto suo marito. This was a crucial part of his charge, because it indicated that he was seeking a maximum penalty for the offense. The statutes at Reggio Emilia distinguished between sex crimes based on two criteria: whether the woman was of good fama, and whether she consented to the act. By claiming his wife was honest in the charge, Guadagninus accused Meninus of a serious crime - the "violation" of an honest married woman - which carried a fine of 100 pounds for Meninus, and if proven, could have carried a capital penalty for Dominica.

18 Nellus de Sancto Geminiano, De testibus, 175, in Tractatus Universi Iuris XI, pt. 1. (Venice: 1584), 216-217.

19 Vallerani, "How Procedures Think," 112.

20 Bartolus, Tractatus testimoniorum 14, p. 241: "Videbatur eius dicto non standum, quia per nullum sensum corporis causam reddit. Dicebam standum esse, sufficit enim sensum exprimere uel aliquid per quod secundum communiter accidentia per sensum habeatur notitia, quia enim uicinus uel consanguineus est, uidet secundum quod communiter accidit uitam et mores. Per uisum ergo causam reddisse videtur, hoc etiam legibus comprobatur." 
Though Meninus answered the summons to appear at court and confessed that everything in the charge was true as it was stated, the next day, his advocate appeared in court, announcing that Meninus had been mistaken, and his confession was contra omnem veritatem. The advocate claimed that the petition made by Guadagninus could not proceed because the charge was based on the premise that Guadagninus and Dominica lived together honestly joined in marriage. This, the lawyer asserted, was not true. In defense of Meninus, he would prove his case through six articles. All of these articles aimed to prove the mala fama of the woman Dominica.

First, the advocate stated his intent to prove that Dominica had lived a dishonest life while she lived with Guadagninus; second, that she was widely known to be a meretrix casalenga, a 'housewife prostitute'; third, that Guadagninus knew about her habits; fourth, that he had expelled her from his home many times because she lived dishonestly, but had always brought her back; fifth, that he had even cut her hair because she lived dishonestly; and sixth, and most importantly, that all of these things were public vox et fama. He then provided the court with a list of twenty-one men who, he claimed, could prove these articles. Of these witnesses, the statements of eleven survive in some detail.

To prove Dominica's mala fama, these witnesses—all men—gave detailed testimony describing their own interactions with Dominica. One witness claimed to have slept with her himself. Another stated that he had seen Dominica standing in the doorway of her home, with her hair cut up to her ears. Dominica's neighbor testified that he hardly dared to open his doors because he feared for his grown daughters. He testified that he had seen a man sneaking to Dominica's house via his property, and when he sealed off the cut-through, the man threatened him, saying that he would not be impeded. The rector of the hospital testified that he seen her standing in her doorway, making lewd gestures. Yet another man claimed to have witnessed Dominica conversing with a man who said, "My love, you'll stay alone tonight because Guadagninus is out of town." To this Dominica replied, "No I won't - if he won't stay with me, will you?"

The sixth article of the charge was that Dominica's poor character was public vox et fama in the community, and all the witnesses testified that this was true. ${ }^{21}$ Testimony to the existence of fama was very common, and even alone, such testimony could open an investigation. But sensory knowledge was an integral part of proving the fact of a person's mala fama. The proof of Dominica's mala fama was composed of testimony to individual experiences with her that,

21 ASRe, Giudiziario, Libri delle denunzie, October 19, 1386, vol. 8, fols. 49r-57v. 
if true, supported the factual condition of mala fama. Establishing her mala fama was not a matter of testimony to gossip or rumors - at least, not solely. Rather the men testified to their specific interactions with her, establishing their authority with which to speak on the situation, and lastly confirming the public vox et fama of the charges. In this sense, the men were doing more than confirming Dominica's pre-existing mala fama: they were constructing it, converting what might (or might not) have been a bad reputation into legal mala fama through their concrete allegations.

Under municipal law, cases of adultery required more witnesses than usual to prove fama - the statutes at Reggio required at least five witnesses to prove the reputation of a woman involved in a rape or adultery case, instead of the usual two to three witnesses required to prove fama. This is because the degree of the crime in sex assaults or adultery was entirely dependent upon the fama of the woman. Adultery cases and rape cases are notoriously difficult to interpret, not least because they often functioned in parallel with civil disputes over dowry. In Reggio, the civil records do not survive that would allow us to see if these people were involved in any parallel actions, so the charges as stated in the denunciations and the responses of witnesses cannot be properly interpreted. In any case, Meninus's defense was successful: he was condemned to pay only 10 pounds, not the 100 pounds owed by a man committing adultery with a married woman of honest life. It is worth emphasizing here that Meninus's virulent attack on his lover's fama also probably saved her life, as the penalty for an "honest woman" committing adultery was death. Regardless of the path that brought the charge of adultery before the court, we can clearly see the construction of legal mala fama through witness testimony: it is built with alleged facts, not rumors, to create the iusta causa et legitima scientia.

The existence of publica vox et fama was essential, constituting the final point in the list of articles to prove. As in the sixth article of the charges against Dominica, witnesses in inquisitorial trials were usually asked whether the facts to which they testified were publica vox et fama, a phrase which translates awkwardly into English as "public discourse and fame." This question asked witnesses to confirm that outside the court, in the community, public knowledge already existed. Usually, the question was a yes or no question, which did not ask witnesses for further, sensory evidence of their answer, and witnesses usually did not hesitate to confirm the vox et fama of the facts of their testimony. Seldom, when a judge asked a witness if his or her testimony was publica vox et fama, did they answer anything but 'yes.' Yet if the distinctions and questions that arose from legal discussions of fama and its probatory value were so complex and nuanced, how did members of the community-whose knowledge fama was supposed to reflect-understand the concept when 
asked to testify to its existence? At Reggio, this verification of publica vox et fama was usually the last article of the interrogation, so our records offer little help in answering this question. In Bologna, perhaps the most important center of legal education in medieval Europe, judges sometimes continued the questioning to ensure that the witnesses understood exactly what vox et fama meant.

When pressed to define vox et fama, witnesses' answers were in no way uniform. Not infrequently, we find that a witness who readily testified to the vox et fama of his or her testimony could not in fact explain what this meant. For example, a certain Dominicus Bitini, identified as a laborer, testified to the vox et fama of the facts he reported, but when the judge then asked him what fama was, he confessed that he did not know. ${ }^{22}$ This of course does not mean that he had no idea of the concept - only that he was reluctant to venture a definition before the judge. Other witnesses, asked to define fama, answered that it was "what neighbors know," or what was said "fully, by all the people" (plenarie per omnes gentes $)^{23}$ or "publicly, by all the people." ${ }^{24}$ Witnesses sometimes used interchangeably concepts like manifestum, notorium, or fama. These terms had a great deal of consequence in a legal forum, but naturally lay witnesses did not make the same distinctions that jurists did, using these words as a way simply to say that fama is evident to everyone: publica vox et fama is "manifestum" and "what all men know" (homines sciunt), ${ }^{25}$ or "notorious (notorium) to all people, namely, both the great and the little people."26 Fama was that which was said "fully, by all the people" or that which was said publicly (publice) by all people. ${ }^{27}$

How many people were necessary to create fama? Once again, there was no uniform answer to the question, even when the witnesses had legal educations. A certain Dominus Egidius, licensed in canon law, thought it was sufficient that it was said by a majority of people (quod dicitur permaiorem partem gentium), ${ }^{28}$

22 ASB, Curia del Podestà, Notai Forensi, b. 10, fasc. 1, 42r.

23 ASB, Curia del Podestà, Giudici ad maleficia, Libri inquisitionum et testium, b. 253 fasc. 2, 22v, April 20, 1388.

24 ASB, Curia del Podestà, Giudici ad maleficia, Libri inquisitionum et testium, b. 253 fasc. 2, 23r, April 20, 1388.

25 AsB, Curia del Podestà, Notai forensi, b. 10, fasc. 1, fol. 16v.

26 AsB, Curia del Podestà, Giudici ad maleficia, Libri inquisitionum et testium, b. 253, fasc. 2, fol. 22v, 20 April 1388: “... interrogatus quid est publica vox et fama? Dixit id quid est notorium omnibus gentibus videlicet magnis et parvis personis."

27 ASB, Curia del Podestà, Giudici ad maleficia, Libri inquisitionum et testium, b. 253 fasc. 2, fol. 22v, April 20, 1388.

28 ASB, Curia del Podestà, Notai Forensi, b. 10, fasc. 1, 55r. 
while a student of civil law posited that ten were necessary; ${ }^{29}$ another witness, a master in a school, thought that six would be enough; ${ }^{30}$ Guilelmus, a notary and citizen of Bologna, said it would take "twenty, thirty, even forty and however many, as make up the majority." ${ }^{31}$ And a certain Johannes, who held the most esteemed title of "utriumque iuris," said that fama was made sometimes by many, sometimes by fewer people, depending on the kind of business under examination. ${ }^{32}$ Johannes distinguished between what is public and what is notorious, saying that what is public is understood by many, but he admitted that he could not remember the definition of notorium, saying only that he was sure it was defined at the gloss on the chapter concerning the cohabitation of clerics and women. ${ }^{33}$

Difficult to quantify, imperative to understand: fama influenced virtually every aspect of public justice but, inside a scholastic system rife with distinctions and technicalities, this most important concept eluded rigid definitions. In the inquisitio specialis, witnesses to fama figure into arguments for guilt or innocence, appearing in three predominant ways: fama that impugns a defendant (public knowledge that the defendant committed the particular crime in question, or that the defendant was a habitual criminal), which was used for trial initiation or to support a charge; fama that undermines a witness (usually as part of a defense); and, primarily in cases of rape or sexual assault, fama that characterizes the victim in such a way that would negate the charge (as in the above-mentioned case of Dominica, and again, usually as part of a defense).

\section{Semel malus, semper malus? The Presumption of Innocence and Mala Fama}

What presumptions did the judge take with him to the defendants' case? This question is important to consider, because it is judicial power that sets inquisition procedure apart from its predecessors. As Eberhard Schmidt commented,

29 ASB, Curia del Podestà, Giudici ad maleficia, Libri inquisitionum et testium, b. 253, fasc. 2 , fol. 8v, April 18, 1388 .

30 ASB, Curia del Podestà, Notai forensi, b. 10, fasc. 1, fol. $17 \mathrm{~V}$.

31 ASB, Curia del Podestà, Notai forensi, b. 10 fasc. 1, fol. 56 r: “. . . dixit quod viginti, triguinta, et quadraguinta, et quanto plures tanto maiorem faciunt fama."

32 ASB, Curia del Podestà, Notai forensi, b. 10 fasc. 1, fol. 57r: “... interrogatus quod [sic] homines faciunt publicem vocem et famam, dixit quod aliquin plures, aliquin pauciores, iusta qualitate negotii de quo queritum."

33 ASB, Curia del Podestà, Notai forensi, b. 10 fasc. 1, fol. 57r. 
"Only a judge equipped with superhuman capabilities could keep himself in his decisional function free from the... influences of his own instigating and investigating activity" ${ }^{34}$ Yet as we have seen, the judge's instigating and investigating activity was, at Reggio Emilia, somewhat minimized by the role of public officials and private parties. Central to understanding the criminal trial is the determination of whether the judge assumed a prosecutorial role, and whether he worked from an assumption of guilt once the decision was made to move forward with the evidence against a named defendant.

Richard Fraher, in his exploration of the presumption of innocence in medieval canon law, traced the evolution of the axiom non statim qui accusatur reus est, sed qui convincitur criminosus ("He who is accused is not immediately [thought to be] a criminal, but rather he who is convicted is criminal") from pseudo-Jerome to Durantis, but concluded that this tenet was shaken by the advent of inquisitorial procedure. ${ }^{35}$ The principle of semel malus, semper malus ("once bad, always bad"), found in the Liber Sextus and developed into a general legal principle by Dinus de Mugello, allowed mala fama to create a judicial presumption of guilt. Gandinus believed the principle allowed suspects of mala fama to be put to torture directly, without further evidence. Infamy thus changed a person's legal status. ${ }^{36}$ Jurists took different views about the weight and power of fama: Dinus allowed fama to stand only as a partial proof, which was the more common view, though a few jurists like Cynus would have accepted it as a full proof. ${ }^{37}$ Yet as we have seen, in inquisitorial trials at Reggio, not only did the accuser bear the burden of proof, but unless acting in an official capacity, the accuser was also required to post personal surety when the claims were brought to court. At its foundation, the core component of presumption of innocence is simply the requirement that the prosecution should bear the burden of proof, and this is stated explicitly in the Digest: "Proof is

34 Eberhard Schmidt, Lehrkommentar zur Strafprozessordnung und Gerichtsverfassungsgesetz, quoted in John Langbein, Torture and the Law of Proof: Europe and England in the Ancien Régime (Chicago: University of Chicago Press, 1977), 8.

35 Fraher, "Ut nullus describatur reus...," 505. Fraher argues that while the idea of presumption of innocence was enshrined in Durantis's Speculum iuris - albeit with great qualifications - the notion became more and more limited in the later Middle Ages because of the less stringent nature of late medieval proof laws, because of the widespread use of inquisition procedure, and because of the "elaboration" of the use of torture.

36 Antonella Bettoni, "The Perception of 'Social Danger' among Ius Commune Jurists: A Reconstruction of the Concept of Malus in Sixteenth and Seventeenth Century Italian and German Juridical Doctrine," Liverpool Law Review 26 (2005): 55-57.

Stern, "Politics and Law in Renaissance Florence and Venice," 226. 
incumbent upon he who brings a charge, not he who denies it."38 The idea that the defendant is innocent until proven guilty was commonplace in the Middle Ages: as Kenneth Pennington has noted, "The maxims 'the burden of proof lies with the accuser, not the defendant' and 'in doubtful matters the defendant is favored, not the plantiff' were commonplaces of medieval law."39 Fama and public perceptions served as the moderators of truth, and we should carefully consider how-or whether-judicial presumptions were shaped by fama.

Good fama was assumed, because it was the natural state. Mala fama had to be demonstrated, but when it was, the legal status of infamia had serious consequences: it could prevent an individual from bringing an accusation, acting as a witness in a case, ${ }^{40}$ or bearing witness to a testament or any instrumentum publicum..$^{41} \mathrm{~A}$ person of bad fama could not serve as judge or an assessor. ${ }^{42}$ Nor could a person of mala fama serve as a procurator or as a judge, or be ordained without a specific papal dispensation..$^{43}$ Mala fama could create a presumption of guilt in criminal cases. ${ }^{44}$ But it is extremely important to differentiate between these terms, since their modern usage would give us a false impression. Mala fama could create a praesumptio of guilt, and was weighted like a strong piece of circumstantial evidence. But medieval laws of proof differentiated between grades of presumptions, only the strongest of which - the so-called "violent presumption" - was assumed to be factual unless disproven. (The modern use of the phrase 'presumption of innocence' would have been, to a medieval jurist, a violent presumption of innocence, because it refers to an assumption that stands unless it is disproven). Mala fama (unlike notoriety) did not create a so-called "violent presumption" of guilt, which would have reversed the burden of proof.

If it did not reverse the burden of proof, how, exactly, did mala fama change a criminal defendant's standing? When defendants are identified in the

38 Dig. 22.3.2: "Ei incumbit probatio qui dicit, non qui negat." Quoted in Fraher, "Ut nullus describatur reus prius quam convicatur: Presumption of Innocence in Medieval Canon Law," in Proceedings of the Sixth International Congress of Medieval Canon Law, Berkeley, California. Monumenta iuris canonici, Series C, 7 (Vatican City: Biblioteca Apostolica Vaticana, 1985), 493-506.

39 Kenneth Pennington, The Prince and the Law: Sovereignty and Rights in the Western Legal Tradition (Berkeley: University of California Press, 1993), $155^{-56}$.

40 Francesco Migliorino, Fama e infamia: Problemi della società medievale nel pensiero giuridico nei secoli XII e XIII (Catania: Giannotta, 1985), 139-141.

41 Migliorino, Fama e infamia, 146-147.

42 Migliorino, Fama e infamia, 154-157.

43 Peters, "Wounded Names," 68-69.

44 Migliorino, Fama e infamia, 54. 
denunciations that begin criminal trials, the accused are sometimes designated as individuals of mala fama, such as "Antonius, son of Johannes de Pinaziis de Placentia, a thief, and a man of bad condition and fama," ${ }^{45}$ or "Thomaxus de Costa, son of Puzius, and Bartholazus de Costa, son of Albertus, citizens of Bismantova in the district of Reggio, murderers and highwaymen [robatores stratorum] and men of the worst [pessime] condition and fama." ${ }^{\text {"6 }}$ These designations are difficult to interpret. Are they legal definitions or allegations? When inquisitions were initiated ex querela, the victim or their kin presumably controlled to a large extent the accusatory narrative. In these cases, could the descriptor simply be a rhetorical statement made by the framer of the denunciation against the defendant, akin to, "this man that I accuse is a very, very bad man"? This reading is tempting for its simplicity, but it is problematic: first, because terms like mala fama were specific and legally very powerful, and it seems unlikely that they would be used in such a casual way, and secondly, because the designation of mala fama seems to bear a close association with certain crimes. If it were a rhetorical part of the narrative made by the offended party, we might expect it to appear in the denunciations or complaints that initiated assault trials - the most common criminal trials in Reggio-but it never does.

The designation of mala fama only occurs in accusations of the most severe felonies: theft, witchcraft, murder, sexual violence, and treason or rebellion. For example, murder accounts for 56 percent of the cases where the defendant is termed mala fama, but only 8 percent of cases overall. Yet mala fama is not a formulaic claim tied to particular categories of crime: most murderers and many thieves are not described this way. What, particularly, did this designation indicate, and did it affect the defendant?

We can use the data from Reggio to explore some correlations. A sample of 150 trials (266 defendants) for murder, rebellion, sexual violence, theft and robbery - those crimes where mala fama designations sometimes appearshows an overall conviction rate of approximately 91 percent - very close to the 9o percent overall conviction rate for all crimes at Reggio's court. If we then compare conviction rates in this sample for the defendants denoted as mala

45 ASRe, Giudiziario, Libri delle denunzie, October 7, 1389, vol. 13, 79r: "contra et adversus Anthonium filium Johannis de Pinaziis de Placentia furem hominem male conditionis et fame..."

46 ASRe, Giudiziario, Libri delle denunzie, January 18, 1387, vol. 17, fol. 8r: “... contra et adversus Thomaxum de Costa, filium Puzii et Bartholazum de Costa filium Alberti, cives Bismantue districtus Regii homicidas et robatores stratorum ac homines pessime conditione et fame..." 
fama ${ }^{47}$ with those who lack the descriptor, we find that the conviction rate does not significantly vary based on whether the defendants were designated as mala fama: defendants designated mala fama have a 93 percent conviction rate, compared to go percent for those who do not. The designation of mala fama in the denunciation, then, does not appear to correlate to conviction.

But mala fama does correlate to corporal punishment. Of defendants convicted of the above-listed crimes and designated as mala fama, 91 percent were sentenced to corporal punishment or death, compared to 79 percent of defendants without the designation..$^{48}$ Other differences are apparent as well. The contumacy rate among defendants denoted in the charges as mala fama was 75 percent- 28 percent higher than the average contumacy rate. Thirty-three percent of trials against mala fama defendants were initiated ex officio, compared with an average of 15 percent for criminal cases in general. One wonders if the distinction of mala fama in the denunciation may have indicated recidivists and others who appeared to pose a public danger.

Most defendants designated in this way were men. Most, but not all: those rare cases that see a woman acting as a public menace show the courts treating her very much as her male counterparts were treated, most likely including torture, and attaching the same epithets to her name. In 1377, a certain Jacoba and her husband, homicides publici et famosi et homines male conditione et fame, attacked and murdered a man; while her husband stabbed him, Jacoba took a club and bashed his head, breaking the bones of his skull. She and her husband were condemned in absentia to death by decapitation. ${ }^{49}$ Other examples that show women with this denotation in the statement of charges include a woman charged with witchcraft and love magic ${ }^{50}$ and a woman accused of murdering a two-year-old child. ${ }^{51}$ Women accused of engaging in thefts and murders of strangers are very rare. To find another example we have to once again leave Reggio for Bologna, where we find Bartholomea, daughter of Magister Johannes Petrus de Bologna, who was designated "a thief, and a

47 In this sample of 150 trials, 94 defendants in 64 trials are denoted as mala fama.

48 The difference may be greater still, because in order to make a conservative calculation, this sample specifically counts defendants designated as mala fama. However others are designated as malefactores or homicides or robatores stratorum — not technically mala fama, but surely the idea is the same. If those defendants are included with those called mala fama, the distinction between the defendants who received corporal or capital sentences is greater.

49 ASRe, Giudiziario, Libri delle denunzie, October 5, 1377, vol. 4, fols. 47r-48v.

$50 \quad$ ASRe, Giudiziario, Libri delle denunzie, June 21, 1388, vol. 9, fol. 76r-v.

$5^{1} \quad$ ASRe, Giudiziario, Libri delle denunzie, September 14, 1387, vol. 9, fol. 39r-v. 
public and famous thieving woman, of wicked condition, association, life and fama." Charged with no less than ten separate instances of theft, it is likely that her confession was brought by torture, and she was afterwards remanded to jail. ${ }^{52}$

In general, the mala fama designation marks a defendant who committed a major crime, who very often was either not from Reggio or who had no fixed address (vagabundi), and whose crimes had calculation or premeditation or some other egregious characteristics. This mala fama designation is part of the statement of charges, but there is no evidence that this alleged mala fama was formally proven. This brings us to question other epithetic descriptors that sometimes appear in the denunciations. Defendants accused of murder are sometimes noted as homicides, but not always: again, though it is not a fast rule, it seems that the notation tends to occur when the person's crime is not a personal crime, like the murder of a spouse or a personal enemy, but rather the victim is a stranger, or the crime is undertaken together with robbery or kidnapping.

Some defendants are designated robatores stratorum - highway robbers. Men (and occasionally women) accused of 'highway robbery' were generally considered of mala fama, and unsurprisingly, they frequently received a death penalty. But it is worth considering what made a person a highway robber. The roads and mountain passes were dangerous places, and a legitimate fear of this crime pervaded medieval statute law. Jurisdiction over those robatores stratorum especially after 1393 should have, in many instances, rested with the Capitano del divieto, whose purview included the isolated roads of the mountains: in a reform that further limited the scope of the Podestà's authority, the Capitano dei mont $i^{53}$ or the Capitano del divieto was appointed by the signore to hold jurisdiction over the dangerous roads and highways of the contado from his residence outside the city at Montecchio. His power, which in 1393 would be extended even to a merum et mixtum imperium in the countryside, was essentially over banniti, highwaymen, and other criminals, and he was almost like a Podestà of the contado. ${ }^{54}$ The statutes are silent about the duties of this office, which figures rarely in the surviving records. Yet we still find defendants designated as robatores stratorum in trial records. Why?

52 ASB, Curia del Podestà, Giudici ad maleficia, Libri inquisitionum et testium, b. 254 (138889), fols. 144r-147r. December 30, 1388 and following days: “... furtem ac publicem et famosam latram feminam male conditionis conversationis vite et fame..."

53 Grimaldi, La signoria di Barnabò Visconti, 128.

54 Grimaldi, La signoria di Barnabò Visconti, 128. 
When men so designated are summoned to appear in Reggio's court, sometimes - I think significantly — the crime of highway robbery appears linked to rebellion in the contado. This is the case for three men who were hanged as notorious highwaymen and rebels in January of 1375. Cominus son of Johannes and Jacobus de Verziis, both of Bologna, and Johannes of Padua, "thieves, and public and famous thieves, highway robbers, and men of bad condition and fama," 55 went together with "others about whom it is better if we remain silent" to steal two cows. These men were already known for rebellion against Barnabò's rule together with Clericus da Correggio, whose familyalong with the Bioardo de Rubiera-frequently allied with the Este against Milan. ${ }^{56}$ As they tried to move the animals from Castelnuovo to Rubiera, they were captured by the men of Castelnuovo, who "wished to return them to the jurisdiction of our Lord (Barnabò)."57 For cow thieves, the men were certainly heavily armed, bearing arms "offensive and defensive, namely lances and swords." It seems clear that these men were doing more than stealing livestock. They were captured and delivered immediately to the hands of the Podestà, who may have found in this case a way for Reggio to re-assert jurisdiction in the territories of Rubiera, located on the far eastern border of the territory, and closely allied with the Este of Ferrara. ${ }^{58}$ It is likely that they were treated with a summary procedure. ${ }^{59}$ In the same way, a few weeks later, Antonius son of Petrus de Donellis was captured and hanged, also accused of both rebellion against Barnabò and highway robbery, with many of the same features in the charges against him. Unlike Cominus and his associates, Antonius was brought before the judge where he confessed, presumably under torture. ${ }^{60}$

ASRe, Giudiziario, Libri delle denunzie, January 13, 1375, vol. 2, fols. 36r-37r: “. . famosos fures, latrones, robatores stratorum et homines male conditionis et fame..."

$5^{6}$ On the Bioardo family, see Gamberini, La città assediata, 161-5; on the Correggio and their ties to the Este, see Gamberini, La città assediata, 200-202.

57 ASRe, Giudiziario, Libri delle denunzie, January 13, 1375 and following days, vol. 2, fol. 36 r.

$5^{8}$ On Rubiera and the Bioardo, and on Rubiera and its relationship to the Este, see Gamberini, La città assediata, 161-165.

59 ASRe, Giudiziario, Libri delle denunzie, January 13, 1375, vol. 2, fol. 36r-v. A marginal note on the process reads, "Suspensi fuerint per gulam MCCCLXXv die." I assume this means on the day they were captured: marginal glosses indicating executions nearly always either indicate a specific date or else announce that the execution happened "idem die." The record consists only of the denunciation, the narrative of which ends when the men's captors deliver them in fortiam potestatis.

ASRe, Giudiziario, Libri delle denunzie, February 22, 1375, vol. 2, fols. 44r-45v. 
The label of 'robatores stratorum' was of course not necessarily indicative of rebellion against the authority of Milan. But a final example may suggest a bit of further overlap. The above-mentioned Thomaxus de Costa, son of Puzius, and Bartholazus de Costa, son of Albertus, "citizens of Bismantova in the district of Reggio, murderers and highwaymen [robatores stratorum] and men of the worst [pessime] condition and fama", ${ }^{61}$ were accused of homicide by the commune of Lucca. They were caught in the early spring of 1386 , and held prisoner in the castle at Vologno near Bismantova in the territory of Reggio, ${ }^{62}$ and it took until January of 1387 to have the men handed over to Reggio Emilia's criminal court. Both men were citizens of Bismantova, a small territory in the southern, mountainous part of Reggio's diocese which had been granted autonomy by Regina della Scala in the form of a five-year concession of merum et mixtum imperium. When that expired, criminal jurisdiction reverted back to Reggio Emilia, but the Podestà's court had to struggle to bring these defendants back to Reggio for trial, perhaps because transfer was an open admission of Reggio's renewed jurisdiction.

Mala fama, when it is used in criminal law as a descriptor of defendants in statements of charges, seems to be more specific than the idea of bad reputation, perhaps denoting some kind of public menace. Designations of mala fama or other terms like robatores stratorum set a defendant apart as particularly disturbing to the public order (and thus perhaps made them very appropriate targets for inquisition in the public interest, ne crimina remaneant impunita), or even summary justice. The terms used to specify defendants in the denunciations or querela cannot be read at 'face value', nor can they be ignored. However there is absolutely no evidence that any of these designations subverted due process or changed judicial presumptions. Procedurally, even when defendants were described as mala fama, or otherwise indicated as public enemies, they still were granted the due process of law, including the presumption of innocence, if they were the subjects of an inquisition. Yet, while inquisition procedure was a valuable weapon in the war against crime, it was not the only weapon. The 'presumption of innocence' could be subverted in cases where the guilt of the defendant was "notorious" or "manifest." In such cases, a summary procedure was possible that abrogated the right of the defendant to a trial. Defendants whose crimes were considered "notorious" were presumed guilty.

61 ASRe, Giudiziario, Libri delle denunzie, January 18, 1387, vol. 17, fol. 8r.

62 Gamberini, La città assediata, 132, n. 70. 


\section{Ordinem iudiciarium non servare, est iuris ordinem servare: Notoriety and Due Process}

"In the preceding passages, we discussed the method of investigating crimes [de modo cognoscendi de criminibus] according to the order of the law; and there is still another way in which one can proceed in extraordinary matters, namely when the crime is notorious..." ${ }^{63}$ In this way, Durantis introduces his discussion of notorious crimes. In late medieval criminal justice, the notoriety of a deed, distinct from the mala fama of an individual, was grounds for conviction without a trial. Notoriety is not the same thing as fama. Notoriety is certain and incontrovertible knowledge. Fama, as Durantis tells us, is known by most people; notorium is known by all and demonstrable with eyewitnesses. Notorium consists of "irrefutable certainty." 64 Fama was common knowledge; notorium proceeded from eyewitnesses and it existed when no proof to the contrary was possible. ${ }^{65}$ Summary procedure, where the ordo iuris was set aside, was possible in major felony cases if the crime were deemed notorium.

The theory of notoriety that underlay the suspension of legal process was a canon law invention, with no equivalent in the Roman law. ${ }^{66}$ This extremely problematic category of criminal proceeding was of great interest to jurists because the notoriety of an individual or a deed had severe legal consequences, resulting in a summary procedure that essentially denied a defense to the accused. Gratian commented that no one should be condemned without due process, but made an exception for "manifest" crimes (ceterum quae manifesta sunt iudiciarium ordinem non requirunt). ${ }^{67}$ In his seminal work on the hierarchy of medieval proofs, Jean Phillipe Lévy commented that trial processes had

63 Durantis, Speculum iuris, Book III, Part I De notoriis criminibus, p. 44: "In precedentibus de modo cognoscendi de criminibus secundum iuris ordinem ediximus: et quoniam est et alius modus, in quo extraordinarie proceditur, scilicet cum crimen est notorius..."

64 Migliorino, Fama e infamia, 54.

65 Virdi Makinen and Heikki Pihlajamaki, "The Individualization of Crime in Medieval Canon Law." Journal of the History of Ideas, 65:4 (2004): 539; Stern, "Public Fame in the Fifteenth Century," 203.

66 Lévy, La hiérarchie des preuves, 33. On the development of notoriety as a canon law concept, see Lévy, La hiérarchie des preuves, 32-43.

67 Gratian, dictum after C.2 q.1 c.14, quoted in Migliorino, Fama e infamia, 5o. Some twelfth and thirteenth century jurists like Huguccio made distinctions between notorium and manifestum, assigning manifestum a lower degree of publicity than notorium, but still higher than fama. That distinction does not appear to hold in the early years of the fifteenth century. On the distinctions of the earlier jurists, see Migliorino, Fama e infamia, $49-57$. 
a hierarchy in terms of the nature of proofs required. Criminal processes were at the top, requiring proof "clearer than the light of day," civil processes were in the middle, requiring the production of a full proof of some nature, and summary processes stood at the bottom, because they demanded the least proof, resting as they did on the presupposition of the defendant's guilt. ${ }^{68} \mathrm{~A}$ criminal summary process was thus obviously a very difficult proposition for jurists, who, by the end of the thirteenth century, had developed a keen interest in the necessity for due process. ${ }^{69}$ "Ordinary" defendants, the accusati in inquisitorial or accusatorial trials, had the protections of the ordo iuris. "Extraordinary" defendants, accused of notorious crimes, were not protected by the ordo iuris. Rather, on account of their manifestly evident guilt, they were summoned directly to sentencing.

A concern for the potential abuse of such a profound abridgment of a person's right to a defense can be detected throughout Durantis's discussion. He distinguished two important types of notoriety: notoriety of law (notorium iuris) and notoriety of deed (notorium facti).${ }^{70}$ Notorium iuris concerns legal, not factual, culpability. It arises from a legal confession or clear and incontrovertible proof. ${ }^{71} \mathrm{~A}$ crime can be legally notorious even if the accused confessed

\section{Lévy, La hiérarchie des preuves, 31.}

69 Jurists like Johannes Monachus were taking up the question of defendants' rights by the beginning of the fourteenth century. Johannes believed that defendants had the right to a summons, which right came from natural law, not positive law, and thus could not be denied. Therefore, in a process against a notorious defendant, the judge could proceed in a summary fashion in some components of the trial but the summons and the judgment could not be omitted. Johannes also directly asserted the necessity for a presumption of innocence, dismissing even the argument that a judge may have secret knowledge about a crime that has not been made public. To this, Johannes replied that a judge acts in his public capacity, not as a private party, and "he should learn the truth publicly. For a full discussion, see Pennington, The Prince and the Law, 160-164. Durantis's commentary was composed 20-30 years before these discussions were at the forefront, and it was his commentary that went forward as the standard work on legal procedure. Pennington commented that "If [Durantis] had composed his Speculum thirty years later, he probably would have written sympathetically about these issues [defendants' rights to due process]. As it was, future readers found little of the significant changes in the doctrine of due process... The ius commune of early modern Europe may have been the poorer for it." Pennington, The Prince and the Law, 164.

70 Durantis, Speculum iuris, Book III, Part I De notoriis criminibus, §8.8, p. 48.

71 Durantis, Speculum iuris, Book III, Part I De notoriis criminibus, §8.2, p. 49: “... notorium iuris est spontanea confessio, clara probatio, iusta, et irretractabilis diffinitio sentialis.” Migliorino defines notorium iuris, explaining that it is founded on three elements: evidence of the deed, the sentence, and the confession. Migliorino, Fama e infamia, 54. 
falsely. This problem of legal guilt versus factual guilt inspired Durantis's distinction, and further underscored the need for witnesses.

... it often happens that a thing is said to be notorious, that was never a fact, just as if someone confessed falsely that he committed a crime... or if someone knowingly were condemned for a crime that he did not commit. Therefore the law requires evidence of the deed, which comes from the men of that place where the crime was committed. And it is called notorious. For though the man confessed falsely, or was condemned iniquitously, still by this confession or sentence the deed is considered notorious according to the law, until the contrary is demonstrated. ${ }^{72}$

As Durantis demonstrates, notoriety could result from legal proceedings. The ruling of the court could create notoriety even when the facts themselves were incorrect.

It was the second kind of notoriety, notorium facti, that could lead to summary proceedings against the accused. Notorium facti was the pinnacle of the hierarchy of proofs: the evidence was undeniable. ${ }^{73}$ Yet this could be further distinguished by whether the notorium facti was permanent or impermanent: was the notoriety ongoing, or did it happen only in a moment? The permanent notorious fact was impossible to disprove. Antoine de Butrio illustrated it to his students at Bologna by showing them the tower of the Asinelli at the Porta Ravegnana: their observation of it was irrefutable proof of its existence. ${ }^{74}$ Notorious crimes were to be equally clear. But, unlike towers, notorious crimes are not permanent things. Crimes are events, and as such they are transitory and happen in an interval of time that ends: this impermanence led the canonists to further distinctions. ${ }^{75}$

Like other canonists, Durantis agreed with Huguccio that "semel notorium, semper notorium."76 But how to make this clear in a legal sense, to distinguish

72 Durantis, Speculum iuris, Book III, Part I De notoriis criminibus, §8.2, p. 49: “. . Contingeret saepe dici notorium id, quod nunquam factum fuisset, ut si quis de falso confitetur se crimen, de quo agitur, commisse: vel si quis sententialiter condemnetur de crimine, quod nunquam commisit. Requirit ergo ius facti evidentiam, quae se ingerat hominibus loci, ubi committitur: et rei veritas est, ut quid dicatur notorium ... Nam licet falso confiteatur, vel inique condemnetur, tamen per illam confessionem, seu sententiam factum illud habetur de iure pro notorio, donec contrarium ostendatur."

73 Lévy, La hiérarchie des preuves, 45.

74 Lévy, La hiérarchie des preuves, 46.

75 On legal distinctions in notorium facti, see Lévy, La hiérarchie des preuves, 47-53.

76 Durantis, Speculum iuris, Book III, Part I De notoriis criminibus, §8.8, p. 49, cf. Lévy, La hiérarchie des preuves, 48. 
the notorious crime from others? Durantis set forth three criteria that had to be met in order for a crime to be considered notorious. The crime had to be committed in a public place. ${ }^{77}$ It should be committed in the daytime, because otherwise it might not be possible for the witnesses to see clearly. (On this point, Durantis was willing to concede discretion to the judge. $)^{78}$ Finally, the notoriety of a defendant's guilt must be proven by eyewitnesses. This is an important distinction between notoriety and public opinion (communis opinio) because notoriety is proven by eyewitnesses, but it is not possible to prove public opinion with eyewitnesses. ${ }^{79}$ Regarding the number of witnesses necessary to prove notoriety, there was no consensus, though it was generally understood that "notorium denoted a much higher level of publicity than fame." ${ }^{80}$ Durantis reveals debate about this issue:

... so many should be present that their presences can make the crime notorious; neither the presence of a few-of two, or three, or fivesuffices to make something notorious... but rather the notice of the whole neighborhood is required, and [it is required] that all should acclaim that the crime was committed. ${ }^{81}$

Yet even then, the question persisted: how many people make up a neighborhood? Is the notice of a greater part of the neighborhood sufficient? How many people are necessary to prove this knowledge (scientia)? Durantis surveys the variety of opinion on the subject: some say ten men suffice, since that many can make up a parish; others say three men, since that many makes up a collegium. But by this reasoning, two witnesses should suffice, since two people

77 Durantis, Speculum iuris, Book III, Part I De notoriis criminibus, §8.5, p. 49: "Primo ex qualitate loci, ut quia sit in loco publico, nam si in occulto fieret, non esset publicum ..."

78 Durantis, Speculum iuris, Book III, Part I De notoriis criminibus, §8.7, p. 50: “... deprehenditur notorium facti ex temporis qualitate, putà, sit de die, quia si sit de die, quia si de nocte fiat, non possunt homines bene videre, ubi lumen deest... consideret, in principis et ex aliis circumstantiis, quas discretus considerabit."

79 Durantis, Speculum iuris, Book III, Part I De notoriis criminibus, §5.2, p. 48: "Item etiam aliud est communis opinio, quam notorium. Nam communis opinio est tantum de longe praeteritis, et quae probari non possunt per testes de visu ... notorium vero est de praesentibus, vel proxime preteritis, et quae de facili probari possunt per testes de visu..."

8o Stern, "Public Fame in the Fifteenth Century," 203.

81 Durantis, Speculum iuris, Book III, Part I De notoriis criminibus, §8.5, p. 50: “... tot enim debent adesse, quod eorum praesentia faciat crimen notorium, nec paucorum praesentia, puta duorum, vel trium, vel quinque sufficit ad aliquid notorium faciendum ... imo requiritur totius viciniae notitia, et quod omnes communiter crimen commissum fore acclament..." 
can make a congregation. Durantis finally concludes that "There are still others who say, perhaps not wrongly, that it should be left to the discretion of the judge, since it is not expressed in law." 82

Notoriety had to be proven before a judge could require the culprit to appear for sentencing. ${ }^{83}$ The manner of the proof and of the procedure to be followed in notorious crimes depended in part on whether the notoriety was known to the judge himself, or only to others. The most extreme form of this abbreviated procedure was allowed when a crime was committed before both the judge himself and "many others" (tot aliis). In such a situation, the ordo iuris could be fully suspended. It is this form of the trial, where "... neither an accusation, a denunciation, an inquisition or an exception, or even witnesses or other proofs, are necessary ...," that appears to subvert legal process entirely:84

In these cases, therefore, which are known to the judge to be notorious, and also to others, since they happened or came to pass in the presence of the judge and many others... neither an accuser nor a denouncer is required, nor must a libellus (a writ) be given, nor is there a litis contestatio, nor is an oath of calumny sworn, nor [an oath] regarding the veracity [of the complaint], nor is a witness required, nor other proofs, but [in this case] not to serve the judicial order, is the ordo iuris: let [the defendant] be cited to sentencing... ${ }^{85}$

This extreme form of procedure against notorious crimes was intended for use in cases of crimes committed in the presence of the judge as well as many

82 Durantis, Speculum iuris, Book III, Part I De notoriis criminibus, §8.6, p. 50: "Quidam etiam dixerunt, et forte non male, quod arbitrio iudicis relinquitur, quod homines faciant notorium, cum non sit in iure expressum ..."

83 Durantis, Speculum iuris, Book III, Part I De notoriis criminibus, §8.13, p. 51: "Unde iudex non potest sententiare, nisi ei probetur, quia nescit ut iudex...nisi ipso pro tribunali sedente factum fuerit, qui tunc sufficienter intelligitur sibi est probatum, ex quo vidit ut iudex..."

84 Durantis, Speculum iuris, Book III, Part I De notoriis criminibus, §1.1, p. 44: "Scias ergo, quod in notoriis non est necessaria accusatio, vel denunciatio, vel inquisitio, vel exceptio, nec testes etiam, vel aliae probationes..."

85 Durantis, Speculum iuris, Book III, Part I De notoriis criminibus, §8.12, p. 51: "In his ergo, quae sunt notoria iudici et aliis, ut quia facta sunt, vel fuit presente iudice et tot aliis, quod sufficiunt ad notorium faciendum, in hoc inquam notorio iudex non recusatur... nec requiritur accusator, vel denunciator, nec datur libellus, nec fit litis contestatio, nec iuratur de calumnia, vel de veritate, nec requiritur testis, veli alia probatio, imo tunc ordinem iudiciarium non servare, est iuris ordinem servare: citabitur tamen ad sentenciam..." 
others. Procedure would then be dispensed with because there could be no reasonable argument for innocence.

This was not the only form of notorious procedure, though it was the most severe. In the far more likely case that crimes were notorious in the community but not to the judge, there were options for proceeding by a "double path" (duplici via). An official denunciation could be heard (though it was not necessary for a written denunciation to be produced), and in this denunciation, proof of notoriety was required. Then the judge had two options for proceeding: by inquisition ex officio, as he inquired whether there was notoriety, or with another person pursuing the denunciation of notoriety. In either case, the usual ordo iuris was not to be observed, meaning that there was no written denunciation, and no trial. If the defendant denied the charges, witnesses could be heard, but without the usual oaths of calumny and veracity. ${ }^{86}$

The dangers of conviction without due process were clear. Durantis recognized the potential for abuse if the ordo could be entirely suspended without a possibility of defense:

Today however the very office of judges revels in this inquisition [i.e., the kind concerning notorious crimes], for they hinder the defenses, so that it can truly be said, that their office is most widely extended ... for sometimes they hang a man without allowing him to be heard or defended. But let this thing be certain: by law, a legitimate defense should be denied to no one. ${ }^{87}$

Durantis relies upon Hostiensis to explain the particular concerns that procedure for notorious criminals could entail. If there could be a legitimate defense, the defendant was entitled to it; notorious procedure was meant to abbreviate

86 Durantis, Speculum iuris, Book III, Part I De notoriis criminibus, §8.14, p. 51: “... iudex in eo potest duplici via procedere, scilicet per inquisitionem ex officio suo, ut inquiriat, an sit notorium vel etiam alio sibi denunciante et causum prosequente, et probare volente notorium esse, et quocumque modo procedat, non est ordo iudicarius observandus, nec libellus dandus, nec litis contestatio facienda. Reus tamen potest interrogari, an crimen commiserit, quod si negaverit, possunt testes sine alia litis contestatione, et sine iuramento de calunia, seu de veritate dicenda recipi, quia in talibus ordinem iudiciarium non servare, est iuris ordinem servare..."

87 Durantis, Speculum iuris, Book III, Part I De notoriis criminibus, §1.13, p. 45: "Hodie autem valde officium iudicum in hac inquisitione exuberat: ipsi namque adeo defensiones arceant, ut vere dici possit, quod eorum officium latissime patet... nonnumquam enim hominem inauditum et indefensum statim suspendunt. Sed certe quicquid fiat, nulli est de iure legitima defensio deneganda..." 
only those cases where, due to the public and open nature of the crime, there could be no legitimate defense, and the "behavior itself constituted a confession of guilt..." 88

Durantis complained that judges could use this manner of proceeding to abridge defenses. But instead of weakening this power, in his commentary on Durantis's discussion of notorious crimes, Baldus degli Ubaldi added a further blow when he clarified that dilatory exceptions, which could prolong the process, were not to be allowed in notorious cases. ${ }^{89}$ As we will see in the next chapter, these exceptions constituted one of the most important defense strategies in the medieval court; Baldus's opinion would disallow the most common avenue of defense.

Because notorious procedure did not require the written processes necessary in an ordinary inquisition, it is difficult to know how often it was used. Sarah Blanshei's monumental study of justice in medieval Bologna uncovered only one instance where a crime was deemed notorium.${ }^{90}$ The fragmentary evidence that survives at Reggio for this process suggests that it was not used in every circumstance that warranted it, but it was used in some that Durantis would have disallowed. We can find examples in the records of crimes that were committed in front of the court and in front of a judge, and while Durantis's conditions for notoriety appear to be met, these cases were tried as inquisitions according to the ordo iuris. On March 5 , 1380, a certain Johannes de Mutina,

on account of his pride and audacity, said to... Antonius [a servant of Gibertus Rastelli] injurious words, saying to him: "Go hang by the neck. You are a glutton (goliosus)." And the aforesaid deeds were committed and perpetrated by the said Johannes de Mutina ... in the Palazzo Nuovo of the commune of Reggio, at the bench of the jurisdiction of Lord Bernardus de Parma, the judge of the said Lord Podestà, and in his presence... ${ }^{91}$

88 Fraher, "Ut nullus describatur reus," 499. Fraher is describing Gratian's position on crimina manifesta.

89 Baldus degli Ubaldi, "De notoriis criminibus," commentary to Durantis, Speculum iuris, Book III, Part I De notoriis criminibus, p. $5^{2}$.

$90 \quad$ Blanshei, Politics and Justice, 317 n. 14.

91 ASRe, Giudiziario, Libri delle denunzie, March 5, 1380: "Quod predictus Johannes de Mutina per eius superbiam et audaciam dixit predicto Antonio verba iniuriosa dicendo ei, 'vade ad apicandum te per gulas. Tu es unus goliosus', et predicta comissa et perpetrata fuerunt per predictum Johannem de Mutina de anno et mense presentibus super palatio 
Though the crime was committed before the judge, the inquisition was pursued ex querela, not ex officio, and the accuser produced three witnesses to testify for his case. Insults flew with some regularity in the court of the iudex rationis, who decided financial disputes. "You make God sad, the way you can say that I owe you this money, when I gave you part already!" cried a certain Prosperus to Filippinus Fornaxarius before this judge in March of 1380. Again the case came before the criminal judge by a querela. ${ }^{92}$ In 1387 , another case of injurious words actually drove two men to blows before the criminal judge, but once again, the case was prosecuted by a regular inquisition procedure which was initiated by querela. ${ }^{93}$ One inquisitorial trial even described the defendants as notorious before proceeding with a regular inquisitorial process. In this trial, the accused, Johannes de Albinea and Guido de Albinea, were charged with murder and with wishing to "sow discord among the citizens and residents of Reggio." ${ }^{44}$ They were placed under ban for their crime, and a marginal note in the inquisition tells us that in their absence, they were condemned and sentenced to "the loss of their heads and their property." ${ }^{\text {"In }}$ this case, the charge of notorium appears only in relation to the accusation of sowing public discord, and not to the murder itself; it seems likely that the men had already been convicted of that crime in a previous trial that has been lost (and thus had legal notoriety, the notorium iuris that Durantis described). Because the defendants were contumacious, we cannot know how the court would have proceeded had they been caught.

A small window may be opened, purely by chance, by a fragment of a denunciation preserved in the Atti e processi. On 20 April of 1405, the captain of the neighborhood of Sts. Jacobo and Filipo came to the judge to denounce a homicide that occurred in his district. ${ }^{96}$ Andras, a Hungarian, and his wife Diana were accused of murdering a certain Guilelima of Cremona, a resident of Reggio Emilia, by slitting her throat. The denunciation, according to form, narrated the accusation and provided the substantialia, but a marginal note made by the notary indicates that the case did not proceed because Andras

novo comunis Regii ad banchum iurisdictum Domini Bernardi de Parma iudicis dicti Domini Potestatis et in eius presentia..."

92 ASRe, Giudiziario, Libri delle denunzie, March 10, 1380: "Tristis te faciat deus quomodo potes tu dicere quod tibi debeo istos denarios quia tibi dedi partem."

93 ASRe, Giudiziario, Libri delle denunzie, August 20, 1387.

94 ASRe, Giudiziario, Libri delle denunzie, March 23, 1393 and following days.

95 ASRe, Giudiziario, Libri delle denunzie, March 23, 1393 and following days: "1393, die xviiii Aprilis. Condempnati fuerunt superscripti Johannes et Guido et utriusque ipsorum in amissione capite et bonorum suorum."

96 ASRe, Giudiziario, Atti e processi, April 20, 1405. 
and Diana were captured and taken immediately to the gallows, immediate capti et furcis suspensi, because their crime was "manifestum". 97

This record offers us a rare description of a notorious crime and the summary execution of the criminals. It is not surprising that summary execution was carried out against foreign defendants. Ultimately, in the treatment of foreigners in the court system, we might also read something of the strength of urban identity; in territories both urban and rural in the late middle ages, outsiders' position in society was seriously weakened. ${ }^{98}$ This would certainly accord with practice in other places, like Trieste, where penalties for foreigners were usually decided by the arbitrium of the Podestà or Capitano, and where the status of forensis was sometimes equated with that of people of 'vile condition.'99 What is striking about this document is that the crime appeared to meet none of Durantis's criteria: Durantis required that to be notorious, a crime must be committed in daylight; this homicide took place at night. Durantis wrote that a notorious crime takes place in a public space; Guilelima was murdered in her own home. Durantis did not specify a number of witnesses, but concluded that enough witnesses should be present to make it clear that the whole neighborhood was witness to the fact (not the fama) of the event; this denunciation names no witnesses at all. In fact, there is nothing in the denunciation that indicates anything different from many of the other homicides prosecuted by inquisitorial procedure; whatever prompted the court to allow a notorious proceeding here has been lost. And it is only by chance that we know of this proceeding: according to Durantis's manual, nothing in writing was required in a notorious prosecution except a denunciation, which also did not have to be written. In fact, this denunciation was not associated with the prosecution of a notorious crime-it was written to begin an inquest, which ultimately proved unnecessary.

Inquisition procedure had protections for defendants, but inquisition procedure was only one of the processes available to the judge. Any consideration of defendants' rights is shaken by the nature of notorious proceedings. We cannot know how often they occurred, though it is clear that a hundred years earlier, Durantis felt that the power was abused. This is a large gap in our understanding of the weight of due process in court proceedings. And of course we cannot ignore political executions or executions that took place without a trial or even a charge, as when, in 1407 , the lord of Reggio, Ottobuono Terzi, ordered the

\footnotetext{
97 ASRe, Giudiziario, Atti e processi, April 20, 1405.

98 Massimo della Misericordia, "The rural communities," in The Italian Renaissance State, eds. Gamberini and Lazzarini, $278-279$.

Davide, "La giustizia criminale," 237-8.
} 
Podestà to have two men executed. He directed the Podestà to make no mention of his order until both men were in custody, and to then have them taken to the gallows immediately, without stating their offense beyond commenting that this was to be done "on account of something they did against the honor and the state of our aforementioned Lord [Ottobuono], about which it is better, at present, to remain silent."100

Even in modern Western society, the protections of the ordo iuris have been sometimes interpreted to apply to some defendants and not othersconsider the highly controversial treatment of so-called "enemy combatants" in the United States. The idea of notorium in the late medieval period similarly exists in a separate sphere from those "ordinary" defendants whose cases were tried according to the ordo iuris, perhaps because they were believed to pose an extreme social danger. Because no written documentation was required in such cases, there is a virtually insurmountable void in our understanding of them. The only hope for a systematic study might rest in an archive with copious condemnation records, a collection which Reggio Emilia unfortunately does not have, but which might be a subject for future research elsewhere.

100 ASRe, Giudiziario, Atti e processi, August 5, 1407, fol. 51, "Et hoc propter quedam que ipsi comisserunt contra honorem et statum prefati domini nostri que ad presens tacenter pro meliori." 